\title{
Systems Implantation: A Comparative Study and Identification of Gaps in Usual Methodologies
}

\author{
Marisa Panizzi ${ }^{1,2,3}$, Alejandro Hossian ${ }^{4}$, Ramón García-Martínez ${ }^{\dagger 3,5}$ \\ ${ }^{1} \mathrm{PhD}$ Program on Computer Science, National University of La Plata, Argentina \\ ${ }^{2}$ Information Systems Engineering Department, Technological National University at Buenos Aires, Argentina \\ ${ }^{3}$ Information Systems Research Group, National University of Lanus, Argentina \\ ${ }^{4}$ Science Department, Technological National University at Neuquen, Argentina \\ ${ }^{5}$ Scientific Researchs Comission - CIC Bs As, Argentina \\ marisapanizzi@outlook.com, alejandrohossian@yahoo.com.ar,rgm1960@yahoo.com
}

\begin{abstract}
Systems implantation is one the phases of the software process where the human interaction dimension becomes relevant. However, weakness in the supervision of this dimension is a factor that in many cases leads to the failure of the Project. In this work, systematization and control of the implantation activities in the following methodologies is reported: IEEE 1074, Métrica V3, Rational Unified Process, and SCRUM. An instrument for their comparison is proposed, including the rationale for the analytical dimensions used, and a preliminary interpretation of results is presented emphasizing gaps.
\end{abstract}

Keywords-Component; Software processes, human aspects, systems implantation, comparative analysis of processes.

\section{INTRODUCTION}

The evolution in software engineering has provided an array of methodologies and standards, including IEEE 1074 [1], Métrica version 3 [2], Rational Unified Process [3], Scrum [4][5]. In spite of this evolution, authors like Vasconcelos and Werner [6] argue that there are many problems associated to the description of processes in the existing standards or software process models. In [7], the following issues related to software process models are mentioned: (i) there is no definition of a model that comprises the joint representation of the processes, products, people and organization, (ii) aspects like the organization of work, people and their interactions are not formalized in the software process, and (iii) there is no defined process including both the technical and the human part of the process in the model.

The Standish Group Report [8] presents a series of factors influencing the success or failure of a project among which are users' involvement, inaccurate definition of requirements, and specialized resources, all of them related to the human aspects of software development.

The improvements proposed by Requirements Engineering such as IEEE-830 [9], 29148-2011 standards [10] for requirement specification, and the Language Extended Lexicon [11] have helped to resolve issues related to the human aspects of the first link in the software construction chain.
We argue that the implantation process constitutes another link in the software process chain where strong human interaction between systems professionals and the user community is observed. This process is played down because it is the last link in the software process chain. Such underestimation of the process is reflected in the fact that the professional who is assigned the role of implementer or responsible for the delivery of the software product to the customer does not possess the socio-technical competences required to work on such process.

This work was developed on the assumption that software projects fail due to human aspects, roles definition, the interaction between the different roles, the capacities of people performing those roles, among other factors. We state the human dimension and its impact in the implantation process as the working hypothesis. From this hypothesis, the following research question arises: Will a comparative study show that all areas in the information systems implantation process are covered?

This article presents the processes considered (Section II.), the dimensions considered for analysis are described (Section III), results from the comparison are presented along with preliminary interpretations (Section IV), and conclusions and future lines of work (Section V) are provided.

\section{PROCESSES CONSIDERED}

In this section, the methodologies included in the comparative study are presented: the IEEE 1074 Standard [1], the Métrica version 3 methodology [2], the Rational Unified Process [3], and finally the SCRUM methodology [4][5].

\section{DIMENSIONS CONSIDERED In THE ANALYSIS}

This section presents the dimensions considered in the analysis of the implantation process of an information system as well as the project management process associated to it. The dimensions considered are the phases, activities and tasks that make up a process, the proposed tools, the proposed techniques, the artifacts (inputs and products), the required 
roles and the competencies needed for each role.

\section{RESULTS AND INTERPRETATION}

This section presents a table comparing the dimensions of analysis (section A) and the interpretation of the results obtained (section B).

\section{A. Comparative Table of the Dimensions Involved}

Table 1 presents the level of compliance of the analytical dimensions considered for the implantation process in the software development process (see Implantation in the Table) and in the software project management processes (see Project Management in the Table).

In this work, we focused on the implantation process within the software development process. It was also necessary to consider the software project management aspects due to the interactions observed with the implantation process.

Table 1. Comparative Table of the Analytical Dimensions.

\begin{tabular}{|c|c|c|c|c|c|c|c|c|}
\hline & \multicolumn{8}{|c|}{ Methodologies/Processes } \\
\hline & \multicolumn{2}{|c|}{ IEEE 1074} & \multicolumn{2}{|c|}{$\begin{array}{c}\text { METRICA Version } \\
3 \\
\end{array}$} & \multicolumn{2}{|c|}{$\begin{array}{c}\text { Rational Unified } \\
\text { Process }\end{array}$} & \multicolumn{2}{|c|}{ SCRUM } \\
\hline & $\begin{array}{l}\text { Implant } \\
\text { ation }\end{array}$ & $\begin{array}{l}\text { Project } \\
\text { Manag } \\
\text { ement }\end{array}$ & $\begin{array}{l}\text { Implant } \\
\text { ation }\end{array}$ & $\begin{array}{l}\text { Project } \\
\text { Manag } \\
\text { ement }\end{array}$ & $\begin{array}{l}\text { Implant } \\
\text { ation }\end{array}$ & $\begin{array}{l}\text { Project } \\
\text { Manag } \\
\text { ement }\end{array}$ & $\begin{array}{l}\text { Implant } \\
\text { ation }\end{array}$ & $\begin{array}{l}\text { Project } \\
\text { Manag } \\
\text { ement }\end{array}$ \\
\hline $\begin{array}{c}\text { Phases/ } \\
\text { Activities } \\
\text { Tasks }\end{array}$ & & & & & & & & \\
\hline $\begin{array}{l}\text { Propose } \\
\mathrm{d} \text { Tools }\end{array}$ & & & & & & & & \\
\hline $\begin{array}{c}\text { Propose } \\
d \\
\text { Techniqu } \\
\text { es }\end{array}$ & & & & & & & & \\
\hline $\begin{array}{l}\text { Artifacts } \\
\text { (Inputs/ } \\
\text { Products } \\
\quad\end{array}$ & & & & & & & & \\
\hline $\begin{array}{l}\text { Required } \\
\text { Roles }\end{array}$ & & & & & & & & \\
\hline $\begin{array}{l}\text { Compete } \\
\text { nces }\end{array}$ & & & & & & & & \\
\hline
\end{tabular}

Since terminology for the two processes analyzed and the analytical dimensions considered have been unified in the table above, it is necessary to describe the terminology unification process. In the IEEE 1074 standard [1], the implantation process is referred to as installation process and the project management process is included in the project management projects and integral processes. The standard refers to the input information and the information resulting from the processes. In the table above, we called this information "artifacts" (inputs/products).

In the Métrica version 3 [2] methodology, the equivalent term for the implantation process is "Implantation and User Acceptance Phase". The equivalent term for project management is addressed in the Project Management interfaces. Under this methodology, the concept of roles is referred to with the term "participants".

In the Rational Unified Process [3], the equivalent concept for the implantation process is included in the deployment flow and transition phase while the project management process is addressed in the Project Management Flow.
The Rational Unified Process introduces the concept of worker, which, in our analysis, will be included in the Required Roles dimension.

The SCRUM methodology [4][5] does not include a process equivalent to implantation. In turn, the project management process is addressed under that same name.

\section{B. Interpretation of Results}

The results of the analysis of the Comparative Table of the Dimensions Involve (section 4.A.) allowed us to draw the partial conclusions addressed in the following paragraphs.

In relation to the Phases/Activities/Tasks dimension, the IEEE 1074 standard [1], the Métrica version 3 methodology [2] and the Rational Unified Process [3] propose phases, activities and tasks for both process. In the SCRUM methodology [4][5], activities are defined for the project management process but there are no activities for the implantation process.

With regard to the proposed Tools, the IEEE 1074 standard [1] and the Métrica version 3 methodology [2] do not propose any tools for the activities in either process while the Rational Unified Process [3] proposes tools for both processes. The SCRUM methodology [4][5] proposes tools of software project management process.

As for the Proposed Techniques section, the IEEE 1074 standard [1] does not propose any techniques for either process while the Métrica version 3 methodology [2] proposes techniques for both processes. In turn, the Rational Unified Process [3] proposes techniques for the implantation process, and the SCRUM methodology [4][5] proposes techniques for the software project management process.

In relation to the Artifacts (Inputs/Products) dimension, the IEEE 1074 standard [1], the Métrica version 3 methodology [2] and the Rational Unified Process [3] propose artifacts for both processes while the SCRUM methodology [4][5] proposes artifacts for the software project management process only.

With regard to the Required Roles dimension, the IEEE 1074 standard [1] does not propose roles for any of the studied processes. The Métrica version 3 methodology [2] and the Rational Unified Process [3] present roles for both processes while the SCRUM methodology [4][5] proposes roles for the software project management process only.

As for the Competences dimension, none of the methodologies considered include competences for the processes.

\section{CONCLUSIONS AND FUTURE LINES OF WORK}

This work presented a systematic revision of the system implantation sub-process by means of a comparative study of the selected methodologies. As a result, a number of gaps in the sub-process were identified, particularly gaps related to human aspects. Even though there are models that propose roles, the competences that the people playing those roles should have are not presented. 
We were able to create a comparison instrument to study a number of analytical dimensions of the implantation process and the project management process that interacts with it.

Future lines of work include: (a) the need to incorporate more process models or methodologies, such as: Extreme Programing (XP), Dynamic Systems Development Method (DSDM), Rapid Application Development (RAD), Agile Unified Process (AUP); and b) to explore the incorporation of other dimensions to the comparison tool, such as metrics.

\section{ACKNOWLEDGMENT}

The research presented in this paper has been partially funded by: Research Project UTNBA4347 of Technological National University at Buenos Aires, Research Project 80020160400001LA of National University of Lanús and Research Project PIO CONICET-UNLa 22420160100032CO of National Research Council of Science and Technology (CONICET), Argentina. The translation to the English version of the paper was funded by the Information Systems Engineering Department of the Technological National University at Buenos Aires, Argentina.

\section{REFERENCES}

[1] IEEE 1074, 1997. IEEE Standard for Developing Software Life Cycle Processes. IEEE Std 1074 (Revision of IEEE Std 1074-1995; Replaces IEEE Std 1074.1-1995) (1997).

[2] PAe, Métrica versión.3. Portal de Administración Electrónica. Gobierno de España.

[3] IBM. Rational Software. Péraire C., Edwards M, Fernandes A., Mancin E. y Carroll K. The IBM Rational Unified Process for Systems (2007).

[4] Scrum Manager. Palacio J. Gestión de Proyecos SCRUM Manager (Scrum Manager I y II). http://www.scrummanager.net. Página vigente al 17/06/2016 (2015).

[5] Schwaber K. y Sutherland J. La Guía Definitiva de Scrum: Las reglas del juego. (2013)

[6] F. M. de Vasconcelos Jr. and C. M. L. Werner, "Software development process reuse based on patterns". Proceedings of the Ninth International Conference onbSoftware Engineering and Knowledge Engineering (June 1997) pp. 97- 104 (1997)

[7] Acuña S., Juristo. N. Moreno A., Mon A. A software Process Model Handbook for incorporating people `s capabilities. United States of America: Springer Science+Business Media, Inc. (2005).

[8] Report, The Chaos Manifesto: Think Big, Act Small. Stadish Group. (2013).

[9] IEEE 830. IEEE Recommended Practice for Software Requirements Specifications - IEEE Std 830-1998. (1998).

[10] ISO/IEC/IEEE 29148. Software \& Systems Engineering Standards Committee of the IEEE Computer Society, ISO/IEC/IEEE 29148:2011(E), Systems and software engineering - Life cycle processes - Requirements engineering (2011).

[11] LEITE JCSP. Engenharia de Requisitos, Notas Tutoriales, Teaching material of the Requirements Engineering course, Computer Science Department of PUC-Rio, Brazil (1994). 